\title{
Ambient particulate air pollution induces oxidative stress and alterations of mitochondria and gene expression in brown and white adipose tissues
}

Zhaobin Xu ${ }^{1,2}$, Xiaohua Xu ${ }^{2}$, Mianhua Zhong ${ }^{3}$, lan P Hotchkiss ${ }^{4}$, Ryan P Lewandowski ${ }^{4}$, James G Wagner ${ }^{4}$, Lori A Bramble ${ }^{4}$, Yifeng Yang ${ }^{1}$, Aixia Wang ${ }^{5}$, Jack R Harkema ${ }^{4}$, Morton Lippmann ${ }^{3}$, Sanjay Rajagopalan 5,6, Lung-Chi Chen ${ }^{3^{*}}$ and Qinghua Sun ${ }^{2,5,6^{*}}$

\begin{abstract}
Background: Prior studies have demonstrated a link between air pollution and metabolic diseases such as type II diabetes. Changes in adipose tissue and its mitochondrial content/function are closely associated with the development of insulin resistance and attendant metabolic complications. We investigated changes in adipose tissue structure and function in brown and white adipose depots in response to chronic ambient air pollutant exposure in a rodent model.

Methods: Male ApoE knockout (ApoE ${ }^{-1-}$ ) mice inhaled concentrated fine ambient PM (PM $<2.5 \mu \mathrm{m}$ in aerodynamic diameter; $\mathrm{PM}_{2.5}$ ) or filtered air (FA) for 6 hours/day, 5 days/week, for 2 months. We examined superoxide production by dihydroethidium staining; inflammatory responses by immunohistochemistry; and changes in white and brown adipocyte-specific gene profiles by real-time PCR and mitochondria by transmission electron microscopy in response to $\mathrm{PM}_{25}$ exposure in different adipose depots of $\mathrm{ApoE}^{-/-}$mice to understand responses to chronic inhalational stimuli.

Results: Exposure to $\mathrm{PM}_{2.5}$ induced an increase in the production of reactive oxygen species (ROS) in brown adipose depots. Additionally, exposure to $\mathrm{PM}_{2.5}$ decreased expression of uncoupling protein 1 in brown adipose tissue as measured by immunohistochemistry and Western blot. Mitochondrial number was significantly reduced in white (WAT) and brown adipose tissues (BAT), while mitochondrial size was also reduced in BAT. In BAT, PM 2.5 exposure down-regulated brown adipocyte-specific genes, while white adipocyte-specific genes were differentially up-regulated.

Conclusions: $\mathrm{PM}_{2.5}$ exposure triggers oxidative stress in BAT, and results in key alterations in mitochondrial gene expression and mitochondrial alterations that are pronounced in BAT. We postulate that exposure to PM $_{2.5}$ may induce imbalance between white and brown adipose tissue functionality and thereby predispose to metabolic dysfunction.
\end{abstract}

Keywords: air pollution, mitochondria, adipose, oxidative stress, inflammation

\footnotetext{
* Correspondence: Lung-Chi.Chen@nyumc.org; sun.224@osu.edu

${ }^{2}$ Division of Environmental Health Sciences, College of Public Health, The

Ohio State University, Columbus, Ohio, USA

${ }^{3}$ The Department of Environmental Medicine, New York University School of

Medicine, Tuxedo, New York, USA

Full list of author information is available at the end of the article
} 


\section{Background}

Since air pollution has a major impact on public health for the general population, its health effects have been intensively investigated in recent years. Airborne particulate matter (PM) is a complex mixture of chemical and/or biological elements, composed of solid and liquid components that originate from vehicle exhaust, road dust, power plant stacks, forest fires, windblown soil, etc. In particular, airborne fine particulate matter $(\mathrm{PM}<2.5 \mu \mathrm{m}$ in aerodynamic diameter, $\mathrm{PM}_{2.5}$ ), i.e., $\mathrm{PM}$ in the fine and ultrafine ranges, has been implicated in the pathogenesis of cardiovascular disease and lung cancer [1-3].

Adipose tissue is now recognized as not only an energy reservoir for lipid storage, but also an active endocrine organ and an important regulator in glucose homeostasis. Adipose tissues are major actors in both obesity and the emergence of a cluster of associated diseases such as insulin resistance, type 2 diabetes mellitus (T2DM), cardiovascular diseases, and hypertension. There are at least two distinct types of adipose cells, white and brown adipocytes, with opposing effects on energy balance and body weight regulation. White adipose tissue (WAT) is highly adapted to store any excess energy as triglycerides, while brown adipose tissue (BAT), on the other hand, functions to dissipate chemical energy in the form of heat. Recently, A series of investigations have demonstrated that brown and white adipocytes are not sister cells, but rather that brown adipocytes are closely related to myocytes, and both originate from a common "adipomyocyte" precursor $[4,5]$. Among classical white adipocytes, two types may exist: the "genuine" white adipocytes, and "brite" (brown-inwhite) adipocytes. Although "brite" cells do not possess the molecular characteristics of brown adipocytes, they possess the ability to express the uncoupling protein 1 (UCP1), which could mediate heat generation in brown fat uncoupling the respiratory chain and allow for fast substrate oxidation with a low rate of ATP production [6]. Moreover, brown adipose gene expression could be stimulated when mice are maintained at thermoneutrality and under conditions of cold acclimation $[7,8]$.

Mitochondria play a key role in physiological process and are involved in the pathology of many diseases. Little is known about the physiological relevance of mitochondria in adipose tissue. It has been reported by Choo et al [9] that mitochondrial content and function in adipose tissue were reduced in the epididymal fat of type 2 diabetic mice, indicating a potential role for the disruption of adipose tissue mitochondrial content and function in T2DM. Previous studies have shown that fine particulate air pollution inhalation leads to insulin resistance, oxidative stress, alteration of vasomotor tone, vascular and visceral inflammation, adiposity, and atherosclerosis in apolipoprotein $\mathrm{E}$ knockout $\left(\mathrm{ApoE}^{-1-}\right)$ mice and other several mouse models [10-14]. The $\mathrm{ApoE}^{-/-}$mouse is particularly popular in research because of its propensity to spontaneously develop atherosclerotic lesions on a standard chow diet. It is used for studies of hyperlipidemia and atherosclerosis, and has been used extensively in understanding the mechanisms of lipoprotein metabolism and atherosclerosis. The $\mathrm{ApoE}^{-/-}$mice are generated on a C57BL/6 background, and this model is highly susceptible to cardiovascular disease, overweight, insulin resistance, and the development of metabolic syndrome $[10,13,15]$. Although reports show that the function and expression of different adipose genes in white and brown adipose tissues $[16,17]$, to our knowledge no study has investigated the impact of ambient air pollutants simultaneously in various of adipose depots. Therefore, the purpose of this study was to examine changes in white and/or brown adipose tissues in response to $\mathrm{PM}_{2.5}$ exposure in $\mathrm{ApoE}^{-1-}$ mice. We evaluated the role of $\mathrm{PM}_{2.5}$ exposure in inflammatory response, superoxide production, and alterations of mitochondria. Due to the functional differences in WAT and BAT including their vascularity, we hypothesized that $\mathrm{PM}_{2.5}$ exposure may have differential effects on these adipose depots. Thus, we systematically investigated the gene expression patterns in five different defined adipose depots: interscapular BAT (iBAT), mediastinic BAT (mBAT), inguinal WAT (iWAT), retro-peritoneal WAT (rWAT), and epididymal WAT (eWAT) $[18,19]$ in response to $\mathrm{PM}_{2.5}$ exposure.

\section{Methods}

\section{Animals}

Four-week-old male ApoE ${ }^{-1-}$ mice from Jackson Laboratory (Bar Harbor, ME) were housed at constant temperature $\left(22 \pm 2^{\circ} \mathrm{C}\right)$ on a 12 -h light/dark cycle. They were fed ad libitum on standard laboratory mouse chow and had free access to water. The investigation conforms to the Guide for the Care and Use of Laboratory Animals published by the US National Institutes of Health (NIH Publication No. 85-23, revised 1996), and the study protocols were approved by the Institutional Animal Care and Use Committee of Michigan State University and The Ohio State University under protocol \#2008A006-R1.

\section{Exposure to ambient $\mathrm{PM}_{2.5}$}

Animals were exposed to concentrated ambient $\mathrm{PM}_{2.5}$ or filtered air (FA) for 6 hours/day, 5 days/week for a total duration of 2 months in East Lansing, MI from June 7, 2010 to August 6, 2010. The concentrated $\mathrm{PM}_{2.5}$ in the exposure chamber was generated using a versatile aerosol 
concentration enrichment system (VACES) [10]. Inhalation exposures were conducted in one of Michigan State University's mobile air research laboratories (AirCARE 1) [20]. This laboratory is a $53-\mathrm{ft}$ long, 36,000 pound semitrailer with approximately $450 \mathrm{ft}^{2}$ of interior laboratory floor space. Workspace within AirCARE 1 is divided into three work areas for: (1) atmospheric monitoring; (2) inhalation exposure systems for laboratory animals (rats or mice); and (3) biomedical laboratory for laboratory rodent anesthesia, surgery and necropsy, and sample storage. AirCARE 1 is certified by the Association for Assessment and Accreditation of Laboratory Animal Care (AAALAC). For the present study, AirCARE 1 was located on a Michigan State University research farm approximately 1 mile south of the main campus. The site is located over $1000 \mathrm{ft}$ from a medium traffic roadway and $1,500 \mathrm{ft}$ south of a lightly trafficked CSX railway. One interstate highway is located 2 miles south (I-96) and another 2 miles west (I-496) of the site, both of which carry over 25,000 vehicles daily. Michigan State University is located in East Lansing, MI (pop 46,420) in northern Ingham County, and is part of the Lansing Metropolitan Area (pop 453,603). Major emissions sources that could impact the exposure site are the T.B. Simon Power Plant, a 61 megawatt (MW) coal-burning facility located 1.2 miles northwest of the site. The Simon plant emits over 3,000 tons of $\mathrm{SO}_{2}$ and 1,300 tons of $\mathrm{NO}_{\mathrm{x}}$ annually. In downtown Lansing, approximately 4.5 miles west of the site is a $351 \mathrm{MW}$ coal burning power plant (Otto Eckert Station). The Lansing area also has a number of medium to light industries including automotive assembly plants (General Motors), steel (welding and fabricating) and metal processing facilities. Located in mid-Michigan, the site is also affected by regional emission sources in the Midwest, notably from the metropolitan Chicago area, industrial activities along Lake Michigan (e.g., Gary, IN), and coal burning power plants in the Ohio River Valley.

\section{Energy-Dispersive X-Ray Fluorescence (ED-XRF)}

All PM samples for gravimetric and elemental analyses were collected on filters. Filter masses were measured on a microbalance (model MT5, Mettler-Toledo Inc., Highstown, NJ). Chemical composition was analyzed as described elsewhere [12,21].

\section{Dihydroethidium (DHE) staining}

DHE (Invitrogen, Carlsbad, CA), an oxidative fluorescent dye, was used to detect superoxide $\left(\mathrm{O}_{2}{ }^{-}\right)$, which binds to DNA in the nucleus and fluoresces red [22]. Briefly, fresh segments of the brown fat depots were frozen embedded in optimal cutting temperature (OCT) compound, and transverse sections $(10 \mu \mathrm{m})$ were generated with a cryostat and placed on glass slides. Sections were then incubated in chamber with $10 \mu \mathrm{M}$ DHE for 30 minutes at room temperature in a humidified chamber protected from light. Images were obtained with a fluorescent microscope. The excitation wavelength was $488 \mathrm{~nm}$, and emission fluorescence was detected with the use of a 585 $\mathrm{nm}$ filter. Quantification of fluorescence intensity was determined by counting the number of positive stained nuclei in 10 random fields.

\section{Quantitative real-time PCR}

Total RNA was isolated using TRIzol reagent as instructed by the manufacturer (Invitrogen, Carlsbad, CA), and reverse-transcribed to cDNA using the High Capacity cDNA Reverse Transcription Kit (Applied Biosystems, Foster City, CA). The quantitative real-time PCR analysis was performed with a light480 real-time PCR System (Roche Applied Science) following the standard procedure. Real-time PCR primer sequences including uncoupling protein $1\left(U_{c p 1)}\right.$, peroxisome proliferator-activated receptor $-\gamma$ coactivator $1-\alpha(P g c-1 \alpha)$, elongation of very long chain fatty acids 3 (Elovl3), type 2 iodothyronine deiondinase (Dio2), homeobox C9 (Hoxc9), insulin-like growth factor binding protein $3(I g f b p 3)$, dermatopontin $(D p t)$, and $\beta$-actin are showed in Table 1 . Fold changes of mRNA levels were determined after normalization to internal control $\beta$-actin RNA levels.

\section{Transmission electron microscopy (TEM)}

Fat tissues were excised into small pieces $\left(<1 \mathrm{~mm}^{3}\right)$ and fixed with $2.5 \%$ glutaraldehyde $(0.1 \mathrm{M}$ phosphate buffer, $\mathrm{pH}$ 7.4) for 3 hours. Each specimen was post-fixed in 1\% osmium tetroxide for 1 hour and dehydrated through a graded series of ethanol concentrations before being embedded in Eponate 12 resin, sectioned at a thickness of $80 \mathrm{~nm}$ and stained by $2 \%$ aqueous uranyl acetate followed by lead citrate. The grids were then observed in a Technai G2 Spirit TEM (FEI Company, Hillsboro, OR). Quantitative analyses were carried out at a magnification of $\times 18500$. An average of six to seven visual fields was evaluated for mitochondria analysis. The size of mitochondria was analyzed from randomly delineated in five to eight micrographs per group by NIH ImageJ software.

\section{Immunohistochemistry}

Tissues were fixed overnight at room temperature in $4 \%$ formaldehyde, dehydrated in graded ethanol, followed by permeation in xylene and paraffin embedding. Fivemicrometer-thick sections were deparaffinized and subjected to heat-induced antigen retrieval by incubation in Retrieve-all-1 unmasking solution (Signet Labs, Dedham, MA) for 15 minutes at $95^{\circ} \mathrm{C}$. The slides were dipped in $0.3 \% \mathrm{H}_{2} \mathrm{O}_{2}$ for $10 \mathrm{~min}$ to quench the endogenous 


\begin{tabular}{|c|c|c|}
\hline Gene & Forward primer $\left(5^{\prime}-3^{\prime}\right)$ & Reverse primer $\left(5^{\prime}-3^{\prime}\right)$ \\
\hline Hoxc9 & GCAGCAAGCACAAAGAGGAGAAG & GCGTCTGGTACTTGGTGTAGGG \\
\hline lgfbp3 & GCAGCCTAAGCACCTACCTC & TCCTCCTCGGACTCACTGAT \\
\hline Dpt & CTGCCGCTATAGCAAGAGGT & TGGCTTGGGTACTCTGTTGTC \\
\hline Ucp 1 & GGCCTCTACGACTCAGTCCA & TAAGCCGGCTGAGATCTTGT \\
\hline $\operatorname{Pgc}-1 \alpha$ & GAAAGGGCCAAACAGAGAGA & GTAAATCACACGGCGCTCTT \\
\hline Dio2 & AAGGCTGCCGAATGTCAACGAATG & TGCTGGTTCAGACTCACCTTGGAA \\
\hline Elov/3 & GCCTCTCATCCTCTGGTCCT & TGCCATAAACTTCCACATCCT \\
\hline$\beta$-actin & TGTGATGGTGGGAATGGGTCAGAA & TGTGGTGCCAGATCTTCTCCATGT \\
\hline
\end{tabular}

peroxidase. After rinsing in phosphate buffered saline (PBS), the sections were incubated in $1 \%$ BSA/PBS for 10 minutes, followed by overnight incubation with rat anti-mouse F4/80 (AbD Serotec, Raleigh, NC) and rabbit anti-UCP1 (Abcam Cambridge, MA) at $4{ }^{\circ} \mathrm{C}$. Then the slides were rinsed and incubated at room temperature for 2 hours with appropriate horseradish peroxidase (HRP)-conjugated secondary antibodies. After the PBS rinsing, the stain was developed using Fast 3, 3'-diaminobenzidine tablet sets (D4293; Sigma, St. Louis, MO). The sections were then counterstained with hematoxylin and analyzed by a research microscope (Zeiss 510 META, Jena, Germany) with Metamorph V.7.1.2 software (Universal Imaging, West Chester, PA).

\section{Western blotting}

Adipose tissues were homogenized in M-PER mammalian protein extraction reagent (Thermo Fisher Scientific), incubated on ice for $30 \mathrm{~min}$, followed by centrifugation at $12000 \mathrm{~g}$ for 10 minutes at $4^{\circ} \mathrm{C}$. The supernatant was collected and subjected to Western blot analysis. Protein concentrations were determined by BCA assay (Bio-Rad, Hercules, CA). Twenty microgram of protein was separated by SDS-polyacrylamide gel electrophoresis and subsequently transferred to PVDF membrane. After blotting in 5\% non-fat dry milk in PBS-Tween 20 (PBS-T), the membranes were incubated with primary antibodies against $\beta$-actin (Sigma) or UCP1 (Abcam) overnight at $4^{\circ} \mathrm{C}$, and then incubated with the appropriate horseradish peroxidase-linked secondary antibodies for 2 hours at room temperature. Finally, the membranes were visualized with an enhanced chemiluminescence kit (Pierce Biotechnology, Rockford, IL). Band density was quantified by densitometric analysis using NIH ImageJ software.

\section{Statistical analysis}

Data are expressed as mean \pm SEM unless otherwise indicated. The results of experiments were analyzed by unpaired $t$ test using Graphpad Prism v4.0 (GraphPad Software, San Diego, CA). In all cases, $P$ value of $<0.05$ was considered as statistically significant.

\section{Results}

\section{Exposure characterization}

The mean (SD) daily $\mathrm{PM}_{2.5}$ concentration at the study site was $11.82(6.71) \mu \mathrm{g} / \mathrm{m}^{3}$, while the mean concentration of $\mathrm{PM}_{2.5}$ in the exposure chamber was $96.89 \mu \mathrm{g} / \mathrm{m}^{3}$ (approximately 8-fold concentration from ambient level). Because the mice were exposed for 6 hours/day, 5 days/ week, the equivalent $\mathrm{PM}_{2.5}$ concentration to which the mice were exposed to in the chamber normalized over the 2 -month period was $17.30 \mu \mathrm{g} / \mathrm{m}^{3}$. The mean elemental composition, as measured by energy-dispersive $\mathrm{X}$-ray fluorescence (ED-XRF) analysis, is presented in Table 2.

\section{Superoxide $\left(\mathrm{O}_{2}^{-}\right)$generation}

In order to test whether exposure to $\mathrm{PM}_{2.5}$ results in superoxide production in BAT, we performed dihydroethidium (DHE) staining on iBAT depots. As shown in Figures $1 \mathrm{~A}-1 \mathrm{C}, \mathrm{O}_{2}{ }^{-}$production in the iBAT was markedly enhanced in the $\mathrm{PM}_{2.5}$ group compared with the FA group. $\mathrm{O}_{2}{ }^{-}$that was accumulated in the iBAT of the mice exposed to $\mathrm{PM}_{2.5}$ was approximately $80 \%$ increase from FA-exposed controls.

\section{TEM analysis of in situ mitochondria}

To determine whether $\mathrm{PM}_{2.5}$ exposure affects mitochondria in WAT and BAT, transmission electron microscopy (TEM) was used in this study. Figure 2 shows representative TEM images of mitochondria in eWAT (Figures 2A and 2B) and iBAT (Figures 2C and 2D), respectively, and the analyses of mitochondria number (Figure 2E) and area (Figure 2F). In the $\mathrm{PM}_{2.5}$-exposed group, the mitochondrial number and area were significantly decreased in the iBAT when compared with the FA group. In addition, the mitochondrial number was also reduced in the eWAT in response to $\mathrm{PM}_{2.5}$ exposure, although we did not find significant differences in the mitochondrial area in these adipose depots.

\section{F4/80 and UCP1 expression}

Adipose tissue macrophages (ATM), which are thought to represent key cellular mediators of adipose tissue 
Table 2 Elemental concentrations of $\mathrm{PM}_{2.5}$ particle during the exposure

\begin{tabular}{|c|c|c|c|c|}
\hline & \multicolumn{2}{|c|}{ Ambient air } & \multicolumn{2}{|c|}{ Exposure to $\mathrm{PM}_{2.5}$} \\
\hline & Mean & s.d. & Mean & s.d. \\
\hline$S$ & 1142.2 & 1045.7 & 10167.9 & 8038.0 \\
\hline Al & 244.9 & 145.2 & 1297.9 & 571.0 \\
\hline $\mathrm{Si}$ & 70.0 & 60.1 & 1166.9 & 918.7 \\
\hline $\mathrm{Ca}$ & 37.9 & 37.8 & 631.7 & 519.5 \\
\hline $\mathrm{Fe}$ & 27.5 & 20.5 & 403.5 & 211.6 \\
\hline $\mathrm{Mg}$ & 64.6 & 73.3 & 365.0 & 281.7 \\
\hline $\mathrm{K}$ & 49.3 & 24.0 & 358.4 & 216.1 \\
\hline $\mathrm{Na}$ & 17.6 & 38.4 & 262.8 & 332.1 \\
\hline $\mathbf{P}$ & 21.5 & 40.6 & 250.6 & 260.9 \\
\hline $\mathrm{Cl}$ & 6.2 & 12.2 & 155.8 & 161.0 \\
\hline $\ln$ & 6.8 & 11.2 & 147.5 & 166.8 \\
\hline $\mathrm{Sb}$ & 19.4 & 15.1 & 141.7 & 127.4 \\
\hline $\mathrm{Ba}$ & 34.1 & 29.9 & 126.7 & 76.9 \\
\hline $\mathrm{Zn}$ & 5.7 & 4.6 & 55.6 & 40.2 \\
\hline Cs & 17.4 & 18.9 & 54.5 & 49.0 \\
\hline $\mathrm{Cd}$ & 7.7 & 31.1 & 44.5 & 185.6 \\
\hline Sc & 10.8 & 7.8 & 39.5 & 23.1 \\
\hline Co & 10.0 & 7.3 & 35.2 & 21.9 \\
\hline $\mathrm{Br}$ & 6.5 & 3.3 & 33.9 & 12.7 \\
\hline Se & 8.1 & 5.6 & 28.2 & 15.0 \\
\hline I & 5.7 & 15.7 & 28.2 & 55.6 \\
\hline v & 8.5 & 5.0 & 27.2 & 12.9 \\
\hline $\mathrm{Mn}$ & 4.1 & 6.0 & 24.9 & 18.8 \\
\hline $\mathrm{Ti}$ & 1.8 & 2.4 & 22.2 & 20.0 \\
\hline $\mathrm{Pb}$ & 4.4 & 6.4 & 21.5 & 21.8 \\
\hline As & 4.3 & 5.2 & 18.2 & 14.9 \\
\hline $\mathrm{Rb}$ & 4.5 & 2.7 & 13.7 & 7.2 \\
\hline $\mathrm{Ge}$ & 3.5 & 4.7 & 11.9 & 11.7 \\
\hline $\mathrm{Cr}$ & 1.4 & 2.2 & 11.5 & 24.7 \\
\hline $\mathrm{Sr}$ & 2.4 & 2.0 & 11.3 & 6.2 \\
\hline $\mathrm{Ga}$ & 2.0 & 3.7 & 11.1 & 10.7 \\
\hline $\mathrm{Te}$ & 2.8 & 7.5 & 10.3 & 36.6 \\
\hline $\mathrm{Ni}$ & 3.0 & 2.5 & 9.8 & 6.9 \\
\hline Sn & 10.5 & 3.0 & 5.6 & 17.4 \\
\hline $\mathrm{Cu}$ & 1.6 & 1.3 & 3.8 & 8.5 \\
\hline
\end{tabular}

Note: unit, $\mathrm{ng} / \mathrm{m}^{3}$. s.d., standard deviation.

inflammatory response and IR development, were examined in mice. As shown in Figure 3, $\mathrm{PM}_{2.5}$ exposure induced a marked increase in macrophage ( $\mathrm{F} 4 / 80^{+}$cells) infiltration in eWAT. Next, we analyzed the changes in uncoupling protein 1 (UCP1) in response to $\mathrm{PM}_{2.5}$ exposure. As shown in Figure 4, the data by immunohistochemical staining for UCP1 on the sections of iBAT (Figure 4) demonstrated that UCP1 expression was significantly decreased in the $\mathrm{PM}_{2.5}$ group. Western blotting data further confirmed down-regulation of UCP1 protein in the iBAT after $\mathrm{PM}_{2.5}$ exposure (Figure 5).

\section{BAT-specific gene expression}

We next determined gene expression in different adipose depots in response to $\mathrm{PM}_{2.5}$ exposure, in terms of the expression of BAT-specific and WAT-specific gene profiles by real-time PCR analysis. UCP1 uncouples substrate oxidation and electron transport through the respiratory chain from ATP production. This is caused by an increased proton leakage over the inner mitochondrial membrane which dissipates the proton motive force as heat instead of ATP synthesis [23,24]. As shown in Figure 6, consistent with the fact that PGC- $1 \alpha$ induces mitochondrial biogenesis and thermogenesis [25], its gene expression was marked in BAT compared with WAT (> 30-fold increased), while the level of Ucp1, which is almost classically associated with BAT function, was enriched more than 600-fold in BAT compared with WAT. The mRNA levels of the BATspecific genes $U_{c p} 1$ and $P g c-1 \alpha$ were however decreased in all defined adipose depots in response to $\mathrm{PM}_{2.5}$ exposure. The levels of down-regulation of both these genes were pronounced in $\mathrm{BBAT}$ and $\mathrm{mBAT}$ in comparison with the WAT depots. The gene expression of Elovl3, which is majorly expressed in BAT [26], was significantly decreased in mBAT by $\mathrm{PM}_{2.5}$ exposure. In addition, Dio2 may catalyze the conversion of T4 (thyroxin) into the active substance T3 (3, 3', 5-triiodothyronine), a process that occurs in all thyroid sensitive tissue but is particularly pronounced in BAT [27]. The mRNA levels of Dio2 were significantly reduced in both iBAT and $\mathrm{mBAT}$ in response to $\mathrm{PM}_{2.5}$ exposure. In this study, we did not find significant differences on BATspecific gene expressions in the eWAT, rWAT and iWAT depots.

\section{WAT-specific gene expression}

We also sought to determine if $\mathrm{PM}_{2.5}$ changed WATspecific gene profiles in different depots. Igfbp3 is a family of six members important for insulin growth factor 1 (Igf-1) transport and storage in close proximity to the Igf-1 receptor (Igf1r), thereby facilitating Igf-1mediated actions [28]. Hoxc9 belongs to the homeobox family of genes, and it is recognized as WAT-specific marker in primary adipocyte cultures [29]. DPT serves as a good gene marker for white adipogenesis and can be seen as a reference gene for the whitening phenomenon. As shown in Figure 7, the mRNA level of Hoxc9 was significantly higher in the iBAT and mBAT depots from $\mathrm{PM}_{2.5}$-exposed group than FA-exposed group. The mRNA level for Igfbp3 was also increased in mBAT in response to $\mathrm{PM}_{2.5}$ exposure. We did not observe significant differences in the gene expressions of Hoxc 9 or $I g f b p 3$ in the WAT, neither was the gene expression of Dpt in BAT or WAT. 

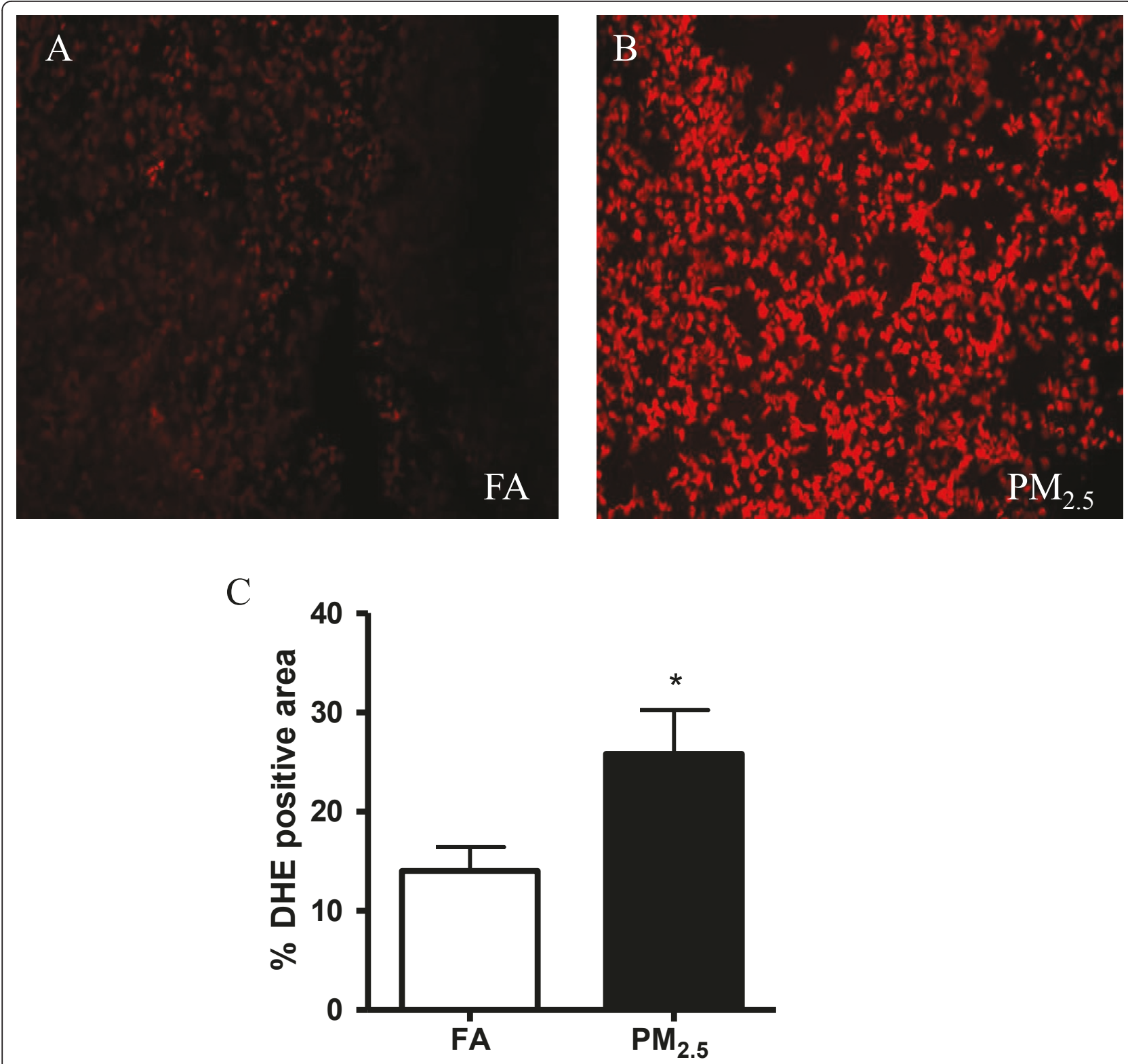

iBAT

Figure 1 Exposure to $\mathrm{PM}_{2.5}$ resulted in increased superoxide production in iBAT. A. DHE staining of adipose tissue sections from the mice exposed to $\mathrm{PM}_{2.5}$ or FA for 2 months. Frozen iBAT sections were stained with DHE (10 $\left.\mu \mathrm{mol} / \mathrm{L}\right)$. The oxidative red fluorescence was analyzed by fluorescent microscope. B. DHE signals were quantified by the percentage of DHE-positive areas in 5 random fields. $\mathrm{n}=8 .{ }^{*} P<0.05$ vs. FA.

\section{Discussion}

In this study, we investigated the effects of inhalation exposure to $\mathrm{PM}_{2.5}$ on oxidative stress, inflammatory response, mitochondria and adipocyte-specific gene expression in adipose tissue depots. To our knowledge, this is the first study to systematically evaluate the effect of ambient $\mathrm{PM}_{2.5}$ on WAT and BAT specific genes in different adipose depots. There are several major findings in this study. First, exposure to $\mathrm{PM}_{2.5}$ resulted in oxidative stress in BAT. Second, exposure to $\mathrm{PM}_{2.5}$ induced changes consistent with reduced BAT functionality and a regression to a WAT phenotype [decrease in BAT specific genes $(P g c-1 \alpha, D i o 2, U c p 1)$ and increase in WAT-specific genes (Hoxc9 and Igfbp 3 )]. This shift was not seen in WAT, when the same genes were analyzed. Finally, mitochondrial number was reduced in both eWAT and iBAT in response to $\mathrm{PM}_{2.5}$ exposure.

Recent studies have implicated $\mathrm{PM}_{2.5}$ in increased adipose inflammation and insulin resistance [11,12], and epidemiological studies indicate that obesity is 


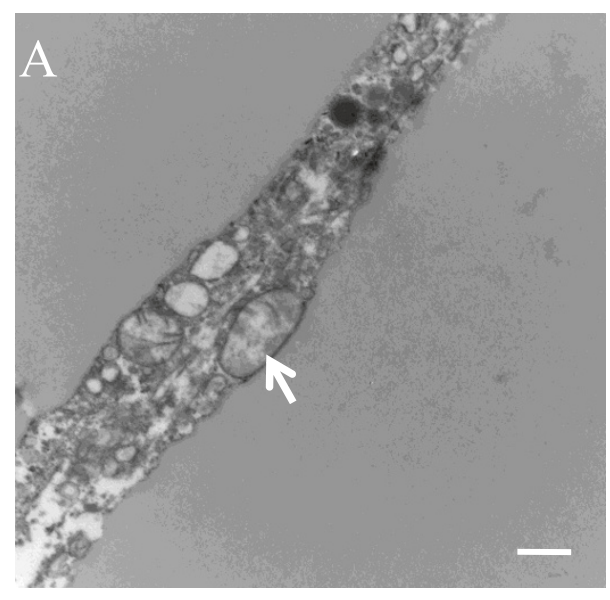

FA

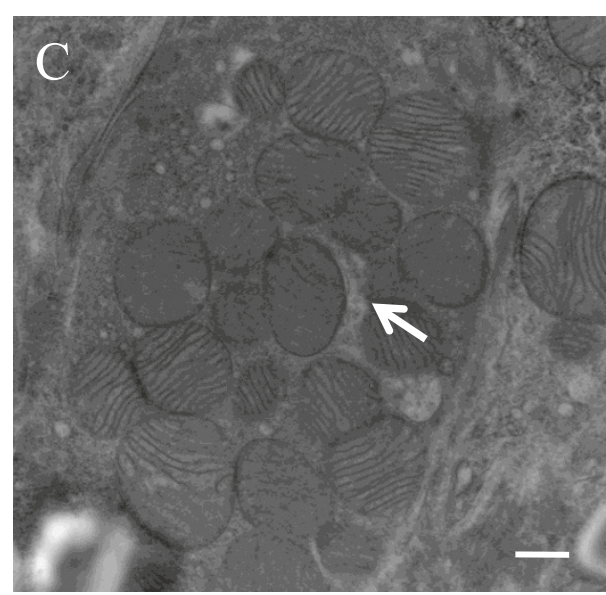

FA

$\mathrm{E}$

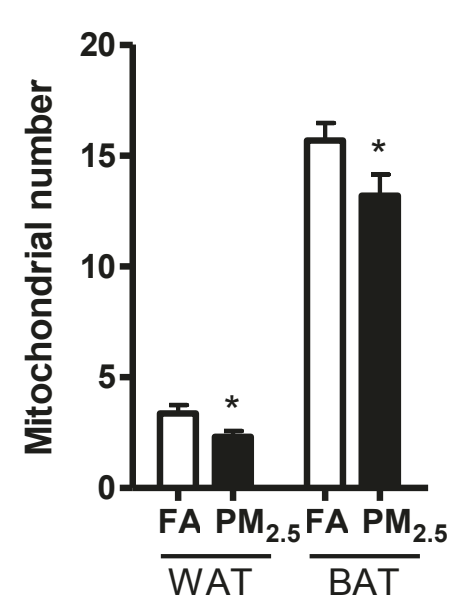

$\mathrm{F}$

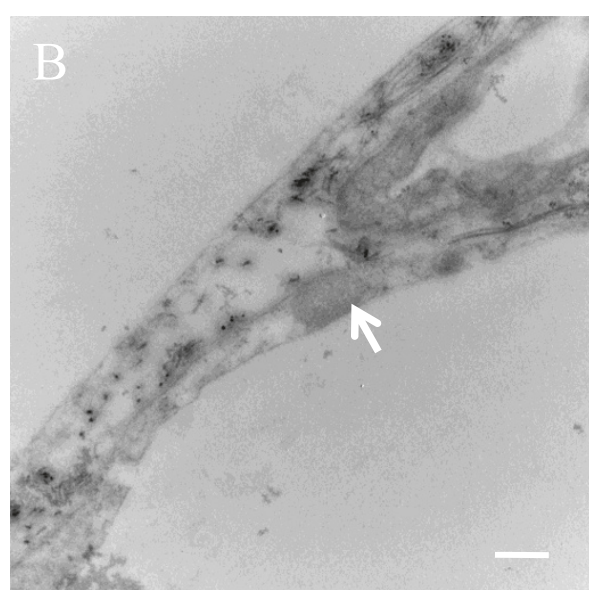

$\mathrm{PM}_{2.5}$

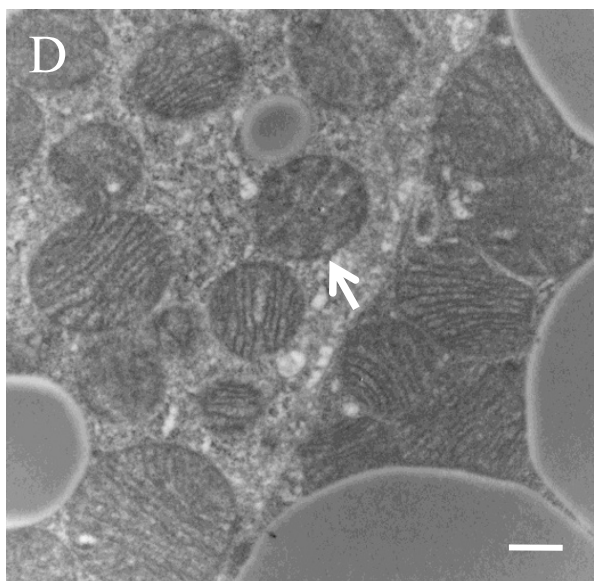

$\mathrm{PM}_{2.5}$
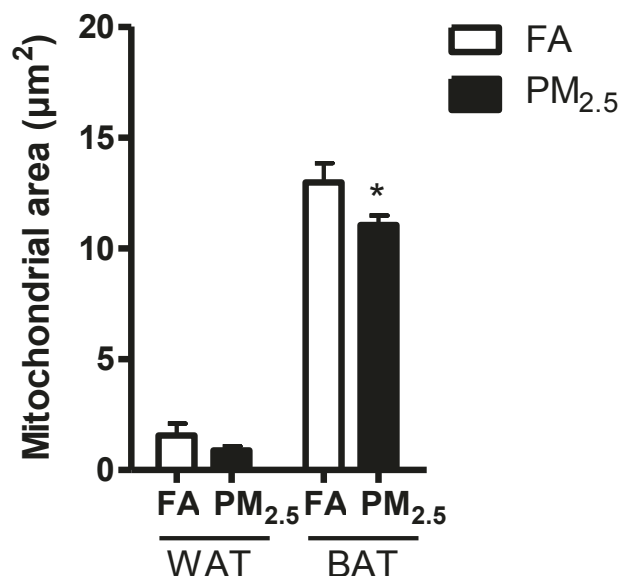

Figure 2 The number and area of mitochondria in the eWAT and iBAT. A-B. Representative TEM images of eWAT. C-D. Representative TEM images of iBAT (Arrows point to mitochondria). E: The analysis of mitochondrial number per field in the eWAT and iBAT. F: The analysis of mitochondrial area per field in the eWAT and iBAT. $n=4 .{ }^{*} P<0.05$ vs. FA. Scale bars represent $500 \mathrm{~nm}$ in panels $A, B, C$ and $D$. 


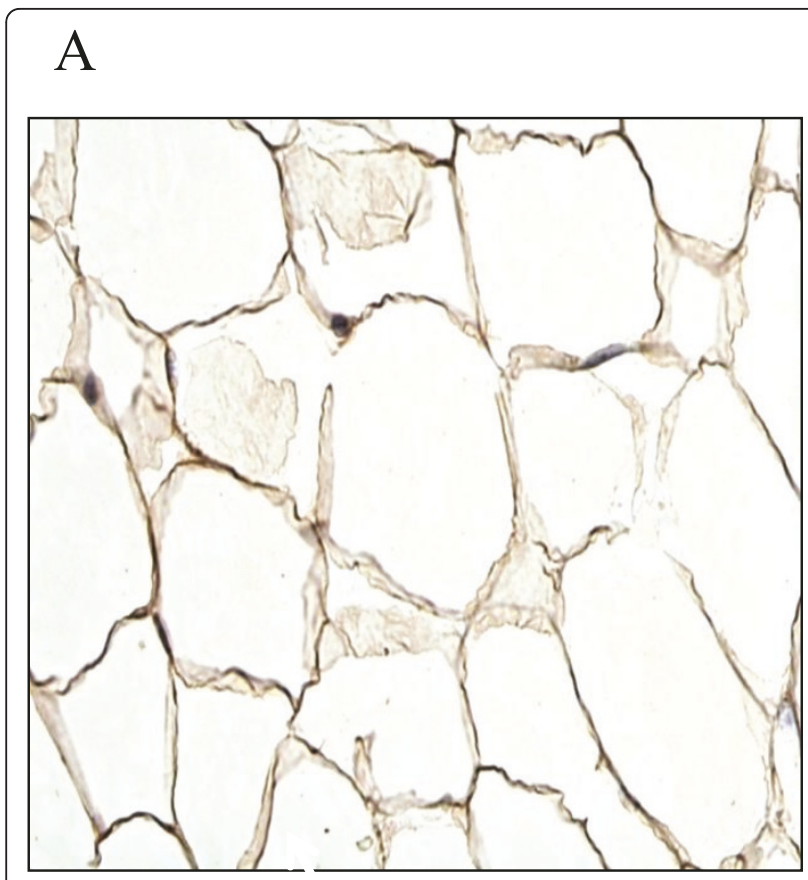

FA

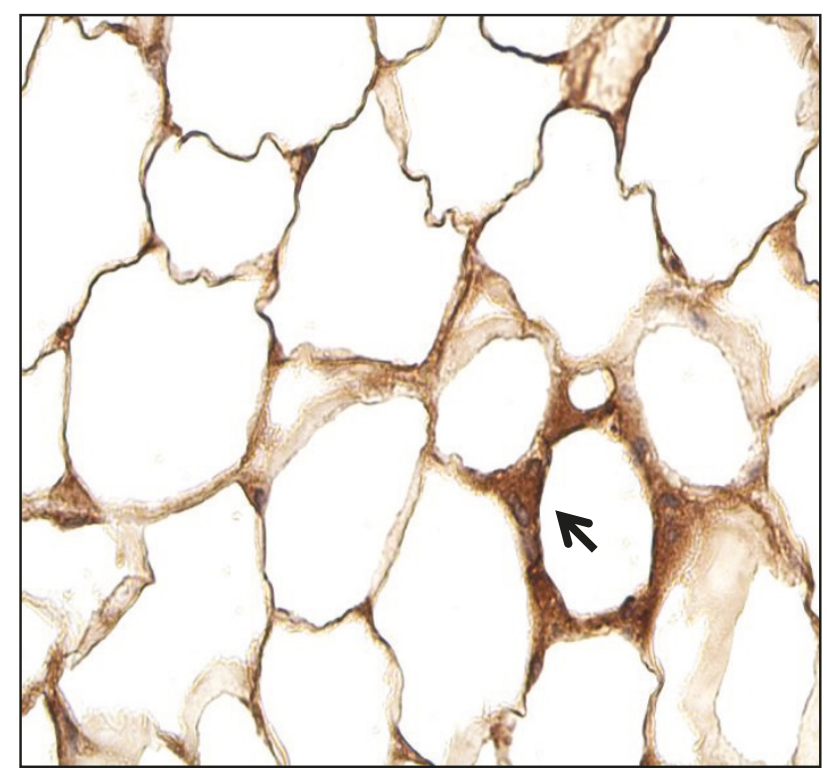

$\mathrm{PM}_{2.5}$

B

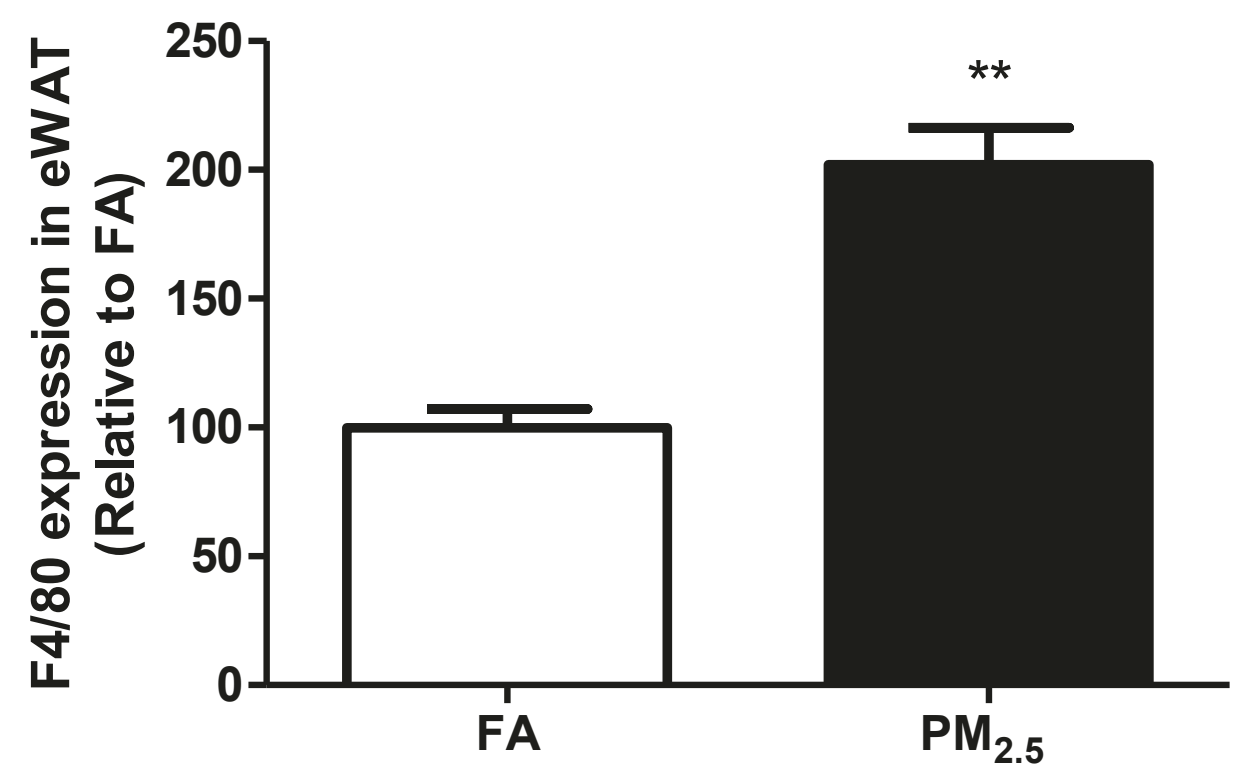

Figure $3 \mathrm{PM}_{2.5}$ exposure increases macrophage infiltration in the eWAT. A. Immunochemistry for macrophage-specific marker F4/80 in sections of eWAT from FA- and $\mathrm{PM}_{2.5}$-exposed mice. B. Quantification of adipose tissue macrophages in eWAT. $\mathrm{n}=4$. ${ }^{* *} P<0.001$ vs. FA. Arrow shows $\mathrm{F} 4 / 80^{+}$macrophages.

associated with adverse health risks, such as hypertension and atherosclerosis [30]. $\mathrm{PM}_{2.5}$ has been shown to stimulate generation of reactive oxygen species (ROS) in cells due to its small diameters and large surface area [31]. To test if $\mathrm{PM}_{2.5}$ exposure could trigger ROS production in vivo, we examined the redox states in BAT.
$\mathrm{O}_{2}{ }^{-}$production was significantly increased in BAT in $\mathrm{PM}_{2.5}$-exposed mice compared with FA-exposed mice.

PM exposure has been demonstrated to cause mitochondrial damage in the pulmonary and cardiovascular systems [32,33], but little is known about the effects of $\mathrm{PM}_{2.5}$ on mitochondria in adipose tissues. In our study, 


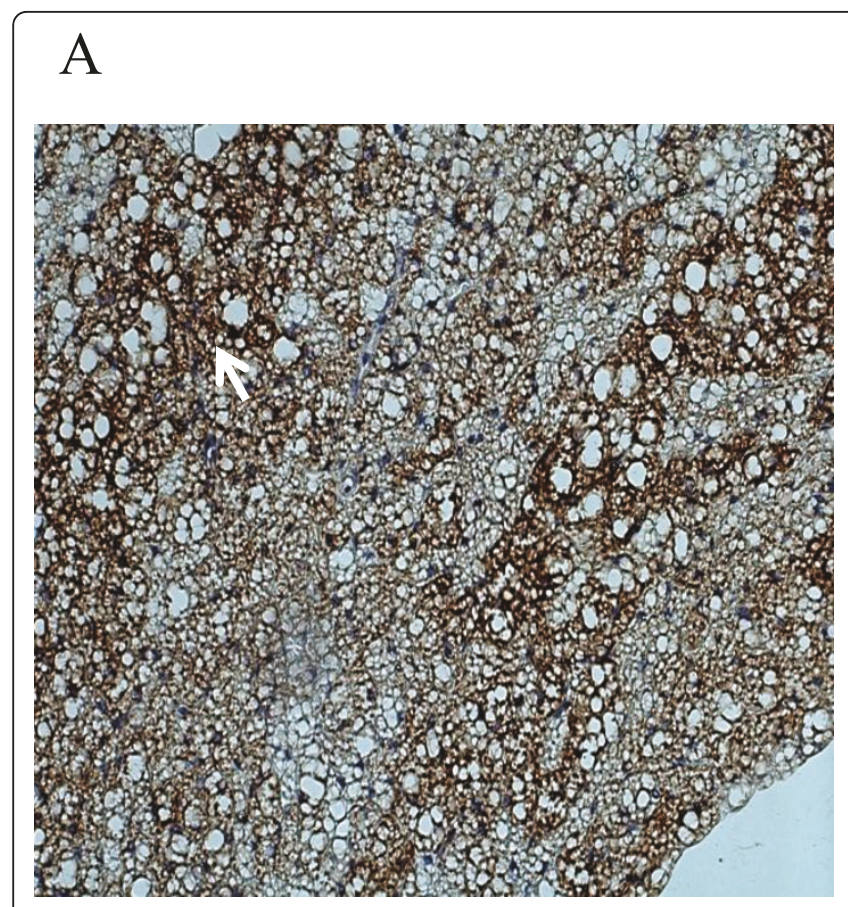

FA

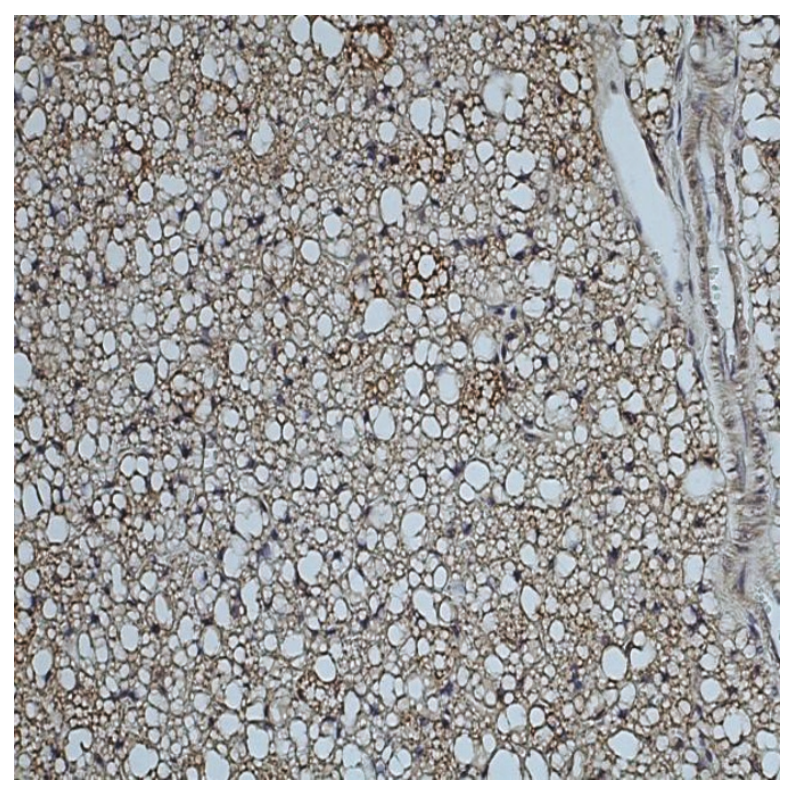

$\mathrm{PM}_{2.5}$

$\mathrm{B}$

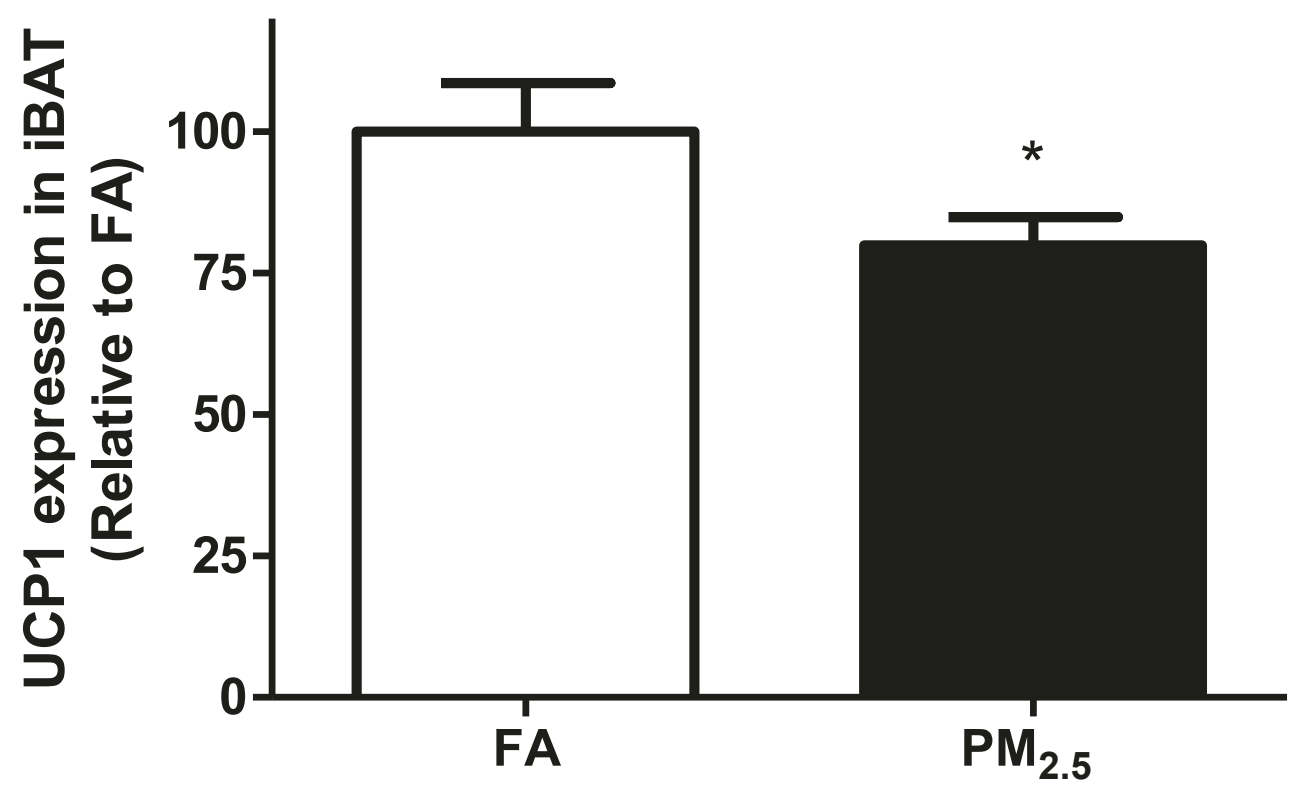

Figure 4 Immunohistochemical examination of uncoupling protein 1 (UCP1) in the iBAT. A. IBAT was stained by antibody against UCP1 and counterstained with hematoxylin. B. Quantification of UCP1 in iBAT. $n=8 * P<0.05$ vs. FA. Arrows show UCP1-positive brown adipocyte staining.

we showed, by TEM measurement, that mitochondrial number was significantly decreased in response to $\mathrm{PM}_{2.5}$ exposure in both eWAT and iBAT, while the mitochondrial area was reduced in the eWAT depots as well. The possible mechanisms may include increased adipocyte membrane permeability or induced apoptosis caused by ROS [34].

BAT functional alterations in response to various stimuli have been investigated for many years but adaptation in BAT as a pathophysiological entity has only been 


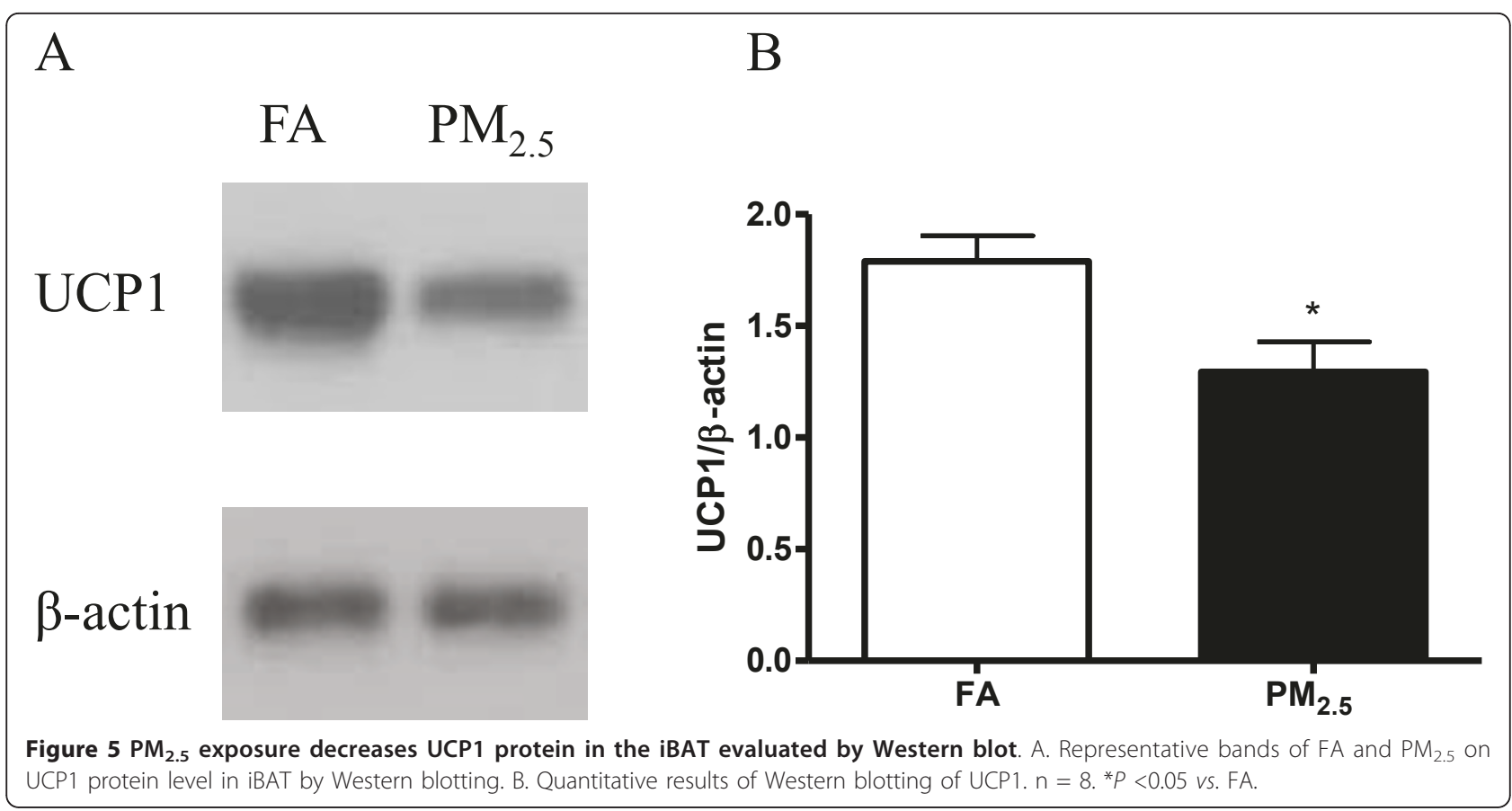

recently investigated. Alterations in BAT function may influence propensity to obesity [35]. Indeed, prior studies suggest alteration of brown adipose gene expression in response to obesity and diabetes [36,37]. In addition to modulation of BAT functionality, there has been considerable interest in "brown-like adipose cells" in WAT. These so called "brite" cells are present in WAT as evidenced by the presence of UCP1 expressing cells in WAT. Studies in cell culture indicate that brown adipocytes and muscle cells share a common origin, which is distinct from white adipocytes [38]. A series of experiments has demonstrated that the UCP1 expressing cells constitute a subset of adipocytes ("brite" adipocytes) with a developmental origin and molecular characteristics [39]. The functional significance of these cells is not known, however; the presence of such cells in WAT raises important questions regarding potential regulatory pathways that may enhance or decrease "brown-fat" like functionality to WAT. In conditions of chronic cold exposure white-to-brown conversion meets the need of thermogenesis, while an obesogenic diet induces brownto-white conversion, to meet the need of storing excess energy [40].

In this study, we found evidence of important changes in BAT in response to $\mathrm{PM}_{2.5}$ exposure. BAT expends energy through sympathetic nervous system-mediated non-shivering thermogenesis, where UCP1 is the key player $[41,42]$. UCP1 was significantly decreased in the iBAT. In addition, morphometric evaluation of TEM images indicated that mitochondrial number and size in BAT and the number (but not size) in WAT were reduced in response to $\mathrm{PM}_{2.5}$ exposure. Taken together, these data suggest that $\mathrm{PM}_{2.5}$ exposure may compromise the functionality of iBAT.

We found that $\mathrm{PM}_{2.5}$ exposure induces down-regulation of Ucp1, Pgc-1 $\alpha$, Dio 2 and Elovl3 genes (change in Elovl3 seen only in mBAT) in classic BAT depots. On the other hand, WAT-specific genes Hoxc 9 and Igfbp 3 were upregulated in brown adipose tissue, indicating brown adipocytes may potentially transform to a white adipose phenotype when stimulated by $\mathrm{PM}_{2.5}$ exposure. Interestingly, a similar shift was not seen in WAT suggesting that this phenotype is relatively specific for BAT.

Why these changes occur in BAT are beyond the scope of this paper, primarily due to limitations of sample size and tissue availability in each group. However, it is interesting to postulate that the increased vascularity of BAT may potentially relate to its vulnerability to air-pollution mediated effects. Future studies would need to be designed to provide significant insights into the roles and mechanisms of $\mathrm{PM}_{2.5}$-associated physiology and pathology.

In summary, our data demonstrate the important effects of $\mathrm{PM}_{2.5}$ exposure on oxidative stress and mitochondrial alterations in adipose tissues. These findings may have a significant impact on our understanding of the adverse effects of particulate air pollution on cardiometabolic diseases, especially in the context of obesity and insulin resistance. 


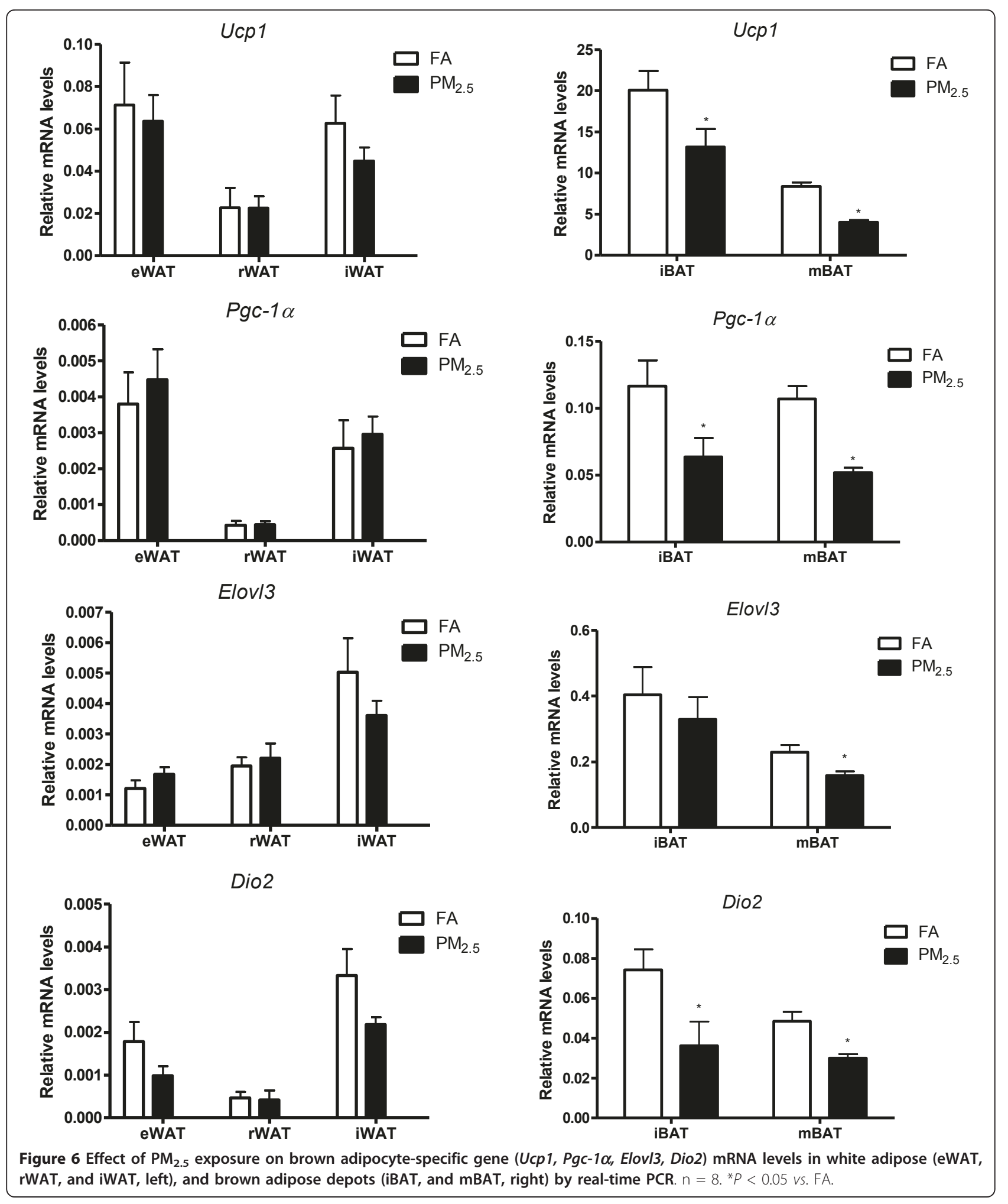




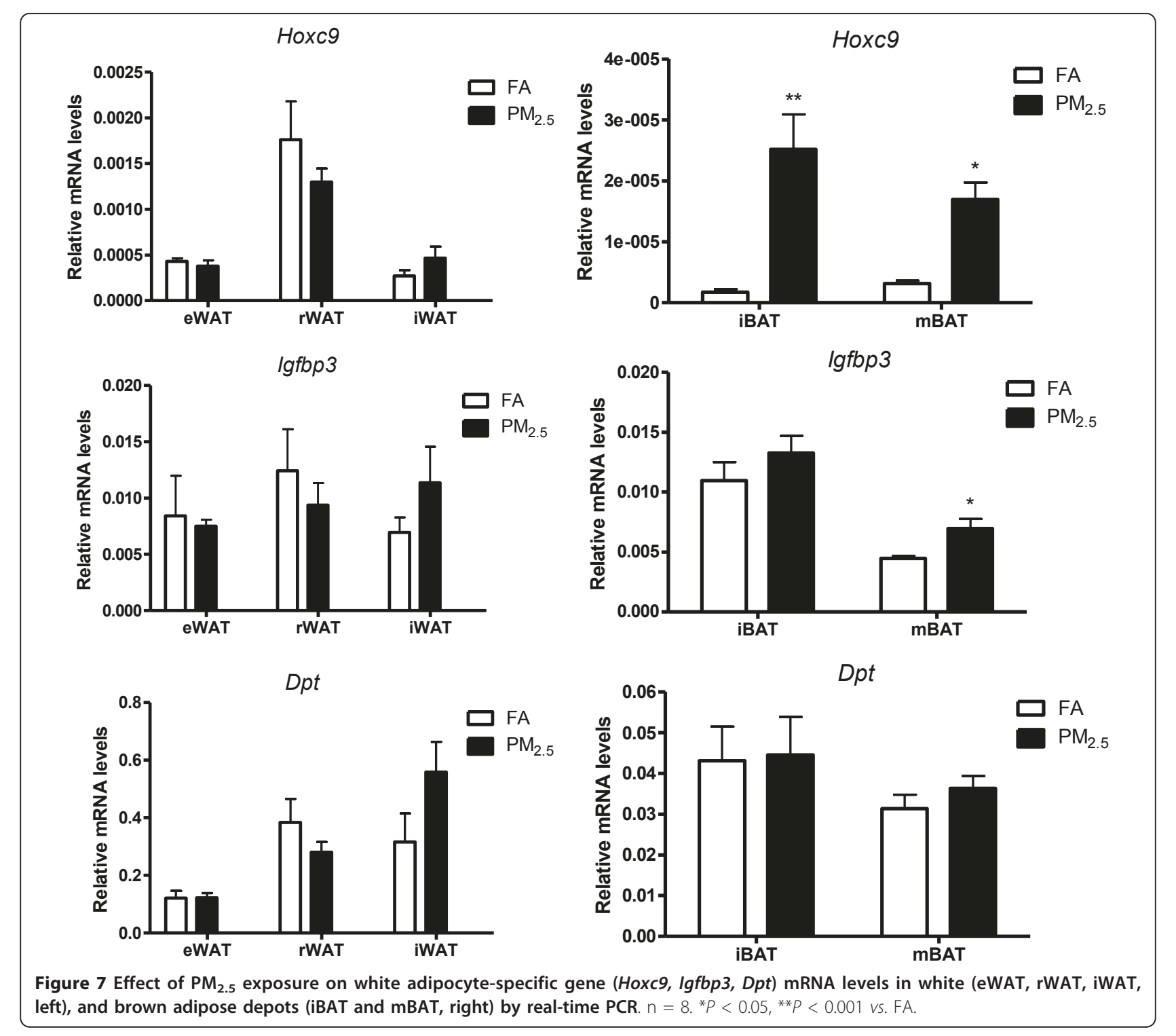

\section{Acknowledgements}

The authors would like to thank the support from Campus Microscopy and Imaging Facility at The Ohio State University for the TEM experiment. This work was supported by National Institute of Health grants ES016588, ES017412, and ES018900 to Dr. Sun, ES015146 and ES017290, and EPA grant R834797-01 to Dr. Rajagopalan, an NPACT Initiative grant from the Health Effects Institute to Drs. Lippmann and Chen, and laboratory facilities supported by NIEHS Center Grant (ES 00260) to New York University School of Medicine.

\section{Author details}

'The Second Xiangya Hospital, Central South University, Changsha, Hunan, China. ${ }^{2}$ Division of Environmental Health Sciences, College of Public Health, The Ohio State University, Columbus, Ohio, USA. ${ }^{3}$ The Department of Environmental Medicine, New York University School of Medicine, Tuxedo, New York, USA. ${ }^{4}$ Center for Integrative Toxicology and Department of Pathobiology and Diagnostic Investigation, Michigan State University, East Lansing, Michigan, USA. ${ }^{5}$ Davis Heart and Lung Research Institute, The Ohio State University, Columbus, Ohio, USA. ${ }^{6}$ Division of Cardiology, College of Medicine, The Ohio State University, Columbus, Ohio, USA.
Authors' contributions

$Z X, X X, M Z$, and $A W$ performed the experiments and contributed to acquisition of data. $Z X, X X, M Z, I P H, R P L, J G W, L A B$, and $Y Y$ analyzed the data and interpreted the results. $M Z, I P H, I P H, R P L, J G W$, and $L A B$

contributed to $\mathrm{PM}_{2.5}$ exposure of the animals. The manuscript was written by $Z X$ and $X X$ and revised critically by $Y Y, Q S, M L$, and SR. All authors read, corrected and approved the manuscript.

\section{Competing interests}

The authors declare that they have no competing interests.

Received: 6 April 2011 Accepted: 11 July 2011 Published: 11 July 2011

\section{References}

1. Schulz H, Harder V, Ibald-Mulli A, Khandoga A, Koenig W, Krombach F, Radykewicz R, Stampfl A, Thorand B, Peters A: Cardiovascular effects of fine and ultrafine particles. J Aerosol Med 2005, 18:1-22.

2. Halonen JI, Lanki T, Yli-Tuomi T, Tiittanen P, Kulmala M, Pekkanen J: Particulate air pollution and acute cardiorespiratory hospital admissions and mortality among the elderly. Epidemiology 2009, 20:143-153. 
3. Pearson JF, Bachireddy C, Shyamprasad S, Goldfine AB, Brownstein JS: Association between fine particulate matter and diabetes prevalence in the U.S. Diabetes Care 2010, 33:2196-2201.

4. Walden TB, Petrovic N, Nedergaard J: PPARalpha does not suppress muscle-associated gene expression in brown adipocytes but does influence expression of factors that fingerprint the brown adipocyte. Biochem Biophys Res Commun 2010, 397:146-151.

5. Tran TT, Kahn CR: Transplantation of adipose tissue and stem cells: role in metabolism and disease. Nat Rev Endocrinol 6:195-213.

6. Petrovic N, Walden TB, Shabalina IG, Timmons JA, Cannon B, Nedergaard J: Chronic peroxisome proliferator-activated receptor gamma (PPARgamma) activation of epididymally derived white adipocyte cultures reveals a population of thermogenically competent, UCP1containing adipocytes molecularly distinct from classic brown adipocytes. J Biol Chem 2010, 285:7153-7164.

7. Teulier L, Rouanet JL, Letexier D, Romestaing C, Belouze M, Rey B, Duchamp C, Roussel D: Cold-acclimation-induced non-shivering thermogenesis in birds is associated with upregulation of avian UCP but not with innate uncoupling or altered ATP efficiency. J Exp Biol 2010, 213:2476-2482.

8. Madsen L, Pedersen LM, Lillefosse HH, Fjaere E, Bronstad I, Hao Q, Petersen RK, Hallenborg P, Ma T, De Matteis R, Araujo P, Mercader J, Bonet ML, Hansen JB, Cannon B, Nedergaard J, Wang J, Cinti S, Voshol P, Doskeland SO, Kristiansen K: UCP1 induction during recruitment of brown adipocytes in white adipose tissue is dependent on cyclooxygenase activity. PLoS One 2010, 5:e11391

9. Choo HJ, Kim JH, Kwon OB, Lee CS, Mun JY, Han SS, Yoon YS, Yoon G, Choi KM, Ko YG: Mitochondria are impaired in the adipocytes of type 2 diabetic mice. Diabetologia 2006, 49:784-791.

10. Sun $Q$, Wang A, Jin X, Natanzon A, Duquaine D, Brook RD, Aguinaldo JG, Fayad ZA, Fuster V, Lippmann M, Chen LC, Rajagopalan S: Long-term air pollution exposure and acceleration of atherosclerosis and vascular inflammation in an animal model. Jama 2005, 294:3003-3010.

11. Sun $Q$, Yue P, Deiuliis JA, Lumeng CN, Kampfrath T, Mikolaj MB, Cai Y, Ostrowski MC, Lu B, Parthasarathy S, Brook RD, Moffatt-Bruce SD, Chen LC, Rajagopalan S: Ambient air pollution exaggerates adipose inflammation and insulin resistance in a mouse model of diet-induced obesity. Circulation 2009, 119:538-546.

12. Xu X, Yavar Z, Verdin M, Ying Z, Mihai G, Kampfrath T, Wang A, Zhong M, Lippmann M, Chen LC, Rajagopalan S, Sun Q: Effect of early particulate air pollution exposure on obesity in mice: role of p47phox. Arterioscler Thromb Vasc Biol 2010, 30:2518-2527.

13. Araujo JA, Barajas B, Kleinman M, Wang X, Bennett BJ, Gong KW, Navab M, Harkema J, Sioutas C, Lusis AJ, Nel AE: Ambient particulate pollutants in the ultrafine range promote early atherosclerosis and systemic oxidative stress. Circ Res 2008, 102:589-596.

14. Riva DR, Magalhaes CB, Lopes AA, Lancas T, Mauad T, Malm O, Valenca SS, Saldiva PH, Faffe DS, Zin WA: Low dose of fine particulate matter (PM2.5) can induce acute oxidative stress, inflammation and pulmonary impairment in healthy mice. Inhal Toxicol 2011, 23:257-267.

15. Kang GS, Gillespie PA, Gunnison A, Moreira AL, Tchou-Wong KM, Chen LC: Long-term inhalation exposure to nickel nanoparticles exacerbated atherosclerosis in a susceptible mouse model. Environ Health Perspect 2011, 119:176-181.

16. Svensson PA, Jernas M, Sjoholm K, Hoffmann JM, Nilsson BE, Hansson M, Carlsson LM: Gene expression in human brown adipose tissue. Int J Mol Med 2010.

17. Dahlman I, Arner P: Genetics of adipose tissue biology. Prog Mol Biol Transl Sci 2010, 94:39-74.

18. Cavallini I, Marino MA, Tonello C, Marzola P, Nicolato E, Fabene PF, Calderan L, Bernardi P, Asperio RM, Nisoli E, Sbarbati A: The hydrolipidic ratio in age-related maturation of adipose tissues. Biomed Pharmacother 2006, 60:139-143.

19. Oliver P, Pico C, Palou A: Ontogenesis of leptin expression in different adipose tissue depots in the rat. Pflugers Arch 2001, 442:383-390.

20. Sirivelu MP, MohanKumar SM, Wagner JG, Harkema JR, MohanKumar PS: Activation of the stress axis and neurochemical alterations in specific brain areas by concentrated ambient particle exposure with concomitant allergic airway disease. Environ Health Perspect 2006, 114:870-874.
21. Maciejczyk P, Chen LC: Effects of subchronic exposures to concentrated ambient particles (CAPs) in mice. VIII. Source-related daily variations in in vitro responses to CAPs. Inhal Toxicol 2005, 17:243-253.

22. Sun Q, Yue P, Ying Z, Cardounel AJ, Brook RD, Devlin R, Hwang JS, Zweier JL, Chen LC, Rajagopalan S: Air pollution exposure potentiates hypertension through reactive oxygen species-mediated activation of Rho/ROCK. Arterioscler Thromb Vasc Biol 2008, 28:1760-1766.

23. Klingenberg M, Echtay KS, Bienengraeber M, Winkler E, Huang SG: Structure-function relationship in UCP1. Int J Obes Relat Metab Disord 1999, 23(Suppl 6):S24-29.

24. Klingenberg M, Huang SG: Structure and function of the uncoupling protein from brown adipose tissue. Biochim Biophys Acta 1999, 1415:271-296.

25. Farmer SR: Molecular determinants of brown adipocyte formation and function. Genes Dev 2008, 22:1269-1275.

26. Jorgensen JA, Zadravec D, Jacobsson A: Norepinephrine and rosiglitazone synergistically induce Elovl3 expression in brown adipocytes. Am J Physiol Endocrinol Metab 2007, 293:E1159-1168.

27. Christoffolete MA, Linardi CC, de Jesus L, Ebina KN, Carvalho SD, Ribeiro MO, Rabelo R, Curcio C, Martins L, Kimura ET, Bianco AC: Mice with targeted disruption of the Dio2 gene have cold-induced overexpression of the uncoupling protein 1 gene but fail to increase brown adipose tissue lipogenesis and adaptive thermogenesis. Diabetes 2004, 53:577-584.

28. Boney CM, Moats-Staats BM, Stiles AD, D'Ercole AJ: Expression of insulinlike growth factor-I (IGF-I) and IGF-binding proteins during adipogenesis. Endocrinology 1994, 135:1863-1868.

29. Gesta S, Bluher M, Yamamoto Y, Norris AW, Berndt J, Kralisch S, Boucher J, Lewis C, Kahn CR: Evidence for a role of developmental genes in the origin of obesity and body fat distribution. Proc Natl Acad Sci USA 2006, 103:6676-6681.

30. Kopelman PG: Obesity as a medical problem. Nature 2000, 404:635-643

31. Akhtar US, McWhinney RD, Rastogi N, Abbatt JP, Evans GJ, Scott JA: Cytotoxic and proinflammatory effects of ambient and source-related particulate matter (PM) in relation to the production of reactive oxygen species (ROS) and cytokine adsorption by particles. Inhal Toxicol 22:37-47.

32. Xia T, Kovochich M, Nel AE: Impairment of mitochondrial function by particulate matter (PM) and their toxic components: implications for PMinduced cardiovascular and lung disease. Front Biosci 2007, 12:1238-1246.

33. Wallenborn JG, Schladweiler MJ, Richards JH, Kodavanti UP: Differential pulmonary and cardiac effects of pulmonary exposure to a panel of particulate matter-associated metals. Toxicol Appl Pharmacol 2009, 241:71-80.

34. Soberanes S, Urich D, Baker CM, Burgess Z, Chiarella SE, Bell EL, Ghio AJ, De Vizcaya-Ruiz A, Liu J, Ridge KM, Kamp DW, Chandel NS, Schumacker PT, Mutlu GM, Budinger GR: Mitochondrial complex III-generated oxidants activate ASK1 and JNK to induce alveolar epithelial cell death following exposure to particulate matter air pollution. J Biol Chem 2009, 284:2176-2186.

35. Marcelin G, Chua S Jr: Contributions of adipocyte lipid metabolism to body fat content and implications for the treatment of obesity. Curr Opin Pharmacol 10:588-593.

36. Ruschke K, Fishbein L, Dietrich A, Kloting N, Tonjes A, Oberbach A, Fasshauer M, Jenkner J, Schon MR, Stumvoll M, Bluher M, Mantzoros CS: Gene expression of PPARgamma and PGC-1alpha in human omental and subcutaneous adipose tissues is related to insulin resistance markers and mediates beneficial effects of physical training. Eur $J$ Endocrinol 162:515-523.

37. Keller MP, Attie AD: Physiological insights gained from gene expression analysis in obesity and diabetes. Annu Rev Nutr 30:341-364.

38. Timmons JA, Wennmalm K, Larsson O, Walden TB, Lassmann T, Petrovic N, Hamilton DL, Gimeno RE, Wahlestedt C, Baar K, Nedergaard J, Cannon B: Myogenic gene expression signature establishes that brown and white adipocytes originate from distinct cell lineages. Proc Natl Acad Sci USA 2007, 104:4401-4406

39. Petrovic N, Walden TB, Shabalina IG, Timmons JA, Cannon B, Nedergaard J: Chronic peroxisome proliferator-activated receptor gamma (PPARgamma) activation of epididymally derived white adipocyte cultures reveals a population of thermogenically competent, UCP1containing adipocytes molecularly distinct from classic brown adipocytes. J Biol Chem 285:7153-7164. 
40. Cinti S: Between brown and white: novel aspects of adipocyte differentiation. Ann Med 2011, 43:104-115.

41. Fromme $\mathrm{T}$, Klingenspor M: Uncoupling protein 1 expression and high fat diets. Am J Physiol Regul Integr Comp Physiol 300(1):R1-8.

42. Kozak LP, Koza RA, Anunciado-Koza R: Brown fat thermogenesis and body weight regulation in mice: relevance to humans. Int J Obes (Lond) 34(Suppl 1):S23-27.

doi:10.1186/1743-8977-8-20

Cite this article as: Xu et al:: Ambient particulate air pollution induces oxidative stress and alterations of mitochondria and gene expression in brown and white adipose tissues. Particle and Fibre Toxicology 2011 8:20.

Submit your next manuscript to BioMed Central and take full advantage of:

- Convenient online submission

- Thorough peer review

- No space constraints or color figure charges

- Immediate publication on acceptance

- Inclusion in PubMed, CAS, Scopus and Google Scholar

- Research which is freely available for redistribution

Submit your manuscript at www.biomedcentral.com/submit
C Biomed Central 